\title{
Improved Method for Isolation of Coupled Mitochondria of Araucaria angustifolia (Bert.) O. Kuntze
}

\author{
André Bellin Mariano ${ }^{1}$, Leonardo Kovalhuk ${ }^{1}$, Caroline Valente ${ }^{1}$, Juliana Maurer- \\ Menestrina $^{1}$, Adaucto Bellarmino Pereira-Netto ${ }^{2}$, Miguel Pedro Guerra ${ }^{3}$ and Eva Gunilla \\ Skare Carnieri ${ }^{1 *}$ \\ ${ }^{1}$ Departamento de Bioquímica e Biologia Molecular; Universidade Federal do Paraná; C. P. 19046; 81.531-990; \\ egscarnieri@ufpr.br; Curitiba - PR - Brazil. 2 Departamento de Botânica; Universidade Federal do Paraná; \\ Curitiba - PR - Brazil. ${ }^{3}$ Departamento de Fitotecnia; Universidade Federal de Santa Catarina; 88.040-900; \\ Florianópolis - SC - Brazil
}

\begin{abstract}
A method for the isolation of coupled mitochondria from the callus of Araucaria angustifolia is described for the first time. Mitochondria were isolated from embryogenic callus of A. angustifolia. They were metabolically active, able to sustain oxidative phosphorylation as shown by respiratory control ratio values, which were about 2.4 when respiring on succinate as substrate. Oxygen uptake experiments, using freeze-thawed disrupted mitochondria, showed the presence of alternative rotenone-insensitive $N A D(P) H$ dehydrogenases, which were stimulated by $C^{2+}$. The procedure now described for the isolation of A. angustifolia mitochondria is an important new tool, allowing the investigation of mitochondrial bioenergetics and metabolism and physiology of plants.
\end{abstract}

Key words: Araucaria angustifolia, callus, plant mitochondria, respiratory chain

\section{INTRODUCTION}

Araucaria angustifolia (Bert.) O. Kuntze, known as "Paraná pine" or "Pinheiro do Paraná" is a conifer species belonging to the Araucariaceae family, which is widespread in southern Brazil, especially in the cold highlands of the States of Paraná, Santa Catarina and Rio Grande do Sul (Guerra et al., 2000; Zandavalli et al., 2004). Several studies have been carried out both with the callus and with tissues of $A$. angustifolia at different developmental stages of differentiation (Fonseca et al., 2000; Guerra et al., 2000), including the extraction of flavones from the latter, but mitochondria of $A$. angustifolia have never been isolated before. In contrast to mammals, the respiratory chain in plant mitochondria has been shown to possess at least four alternative rotenoneinsensitive $\mathrm{NAD}(\mathrm{P}) \mathrm{H}$ dehydrogenases in the inner mitochondrial membrane for transferring electrons to ubiquinone (Melo et al., 1996; Møller, 2001). These enzymes are non-proton pumping, energetically wasteful, and might avoid the production of reactive oxygen species by preventing over-reduction in the respiratory chain (Melo et al., 2001). Two of these alternative $\mathrm{NAD}(\mathrm{P}) \mathrm{H}$ dehydrogenases are found on the outer surface of the inner mitochondrial membrane, facing the intermembrane space and two on the inner surface facing the matrix, similar to what happens with complex I (EC 1.6.5.3) (Møller, 2001). The two external $\mathrm{NAD}(\mathrm{P}) \mathrm{H}$ and the internal

*Author for correspondence 
NADPH dehydrogenases are $\mathrm{Ca}^{2+}$ dependent (Melo et al., 1996). The two external enzymes oxidize the cytosolic pyridine nucleotides and possibly operate in vivo mainly under stress conditions, activated by increased cytosolic concentrations of free $\mathrm{Ca}^{2+}$ that occurs under such situations. The functions of the two internal enzymes are not known, although it has been hypothesized that the internal, rotenone-insensitive NADH dehydrogenase acts as an overflow mechanism when complex I (EC 1.6.5.3) is overburdened (Møller and Palmer, 1982).

We now report for the first time an efficient procedure for the isolation of mitochondria from the callus of $A$. angustifolia and also demonstrate its functionality by oxidative phosphorylation. The presence of alternative rotenone-insensitive $\mathrm{NAD}(\mathrm{P}) \mathrm{H}$ dehydrogenases is reported as well.

\section{MATERIALS AND METHODS}

\section{Plant Material}

The embryogenic callus of $A$. angustifolia (Astarita and Guerra, 2000), grown on BM culture medium (Gupta and Pullman, 1991; Santos et al., 2002) supplemented with $2 \mathrm{mg} . \mathrm{L}^{-1}$ glycine, 0.5 mg. $\mathrm{L}^{-1}$ pyridoxine. $\mathrm{HCl}, 0.5 \mathrm{mg} . \mathrm{L}^{-1}$ nicotinic acid, 1 mg. $\mathrm{L}^{-1}$ thiamine. $\mathrm{HCl}, \quad 500 \mathrm{mg} . \mathrm{L}^{-1}$ casein hydrolysate, $100 \mathrm{mg} . \mathrm{L}^{-1}$ myo-inositol, 1 g.L. $\mathrm{L}^{-1} \mathrm{~L}-$ glutamine, 30 g.L $\mathrm{L}^{-1}$ sucrose, 7 g.L $\mathrm{L}^{-1}$ Phytagar $\left(\right.$ Gibco $\left.^{\circledR}\right), 2 \mu \mathrm{M} 2,4$ dichlorophenoxyacetic acid, $0.5 \mu \mathrm{M}$ benzylaminopurine and $0.5 \mu \mathrm{M}$ kinetin, was used as the source of mitochondria. The $\mathrm{pH}$ of the culture medium was adjusted to 5.8 with $\mathrm{KOH}$ prior to autoclaving at $121^{\circ} \mathrm{C}$ for $20 \mathrm{~min}$. Casein hydrolyzate and L-glutamine solutions were filter sterilized and added to the medium after autoclaving.

\section{Oxygen Uptake}

Oxygen consumption by isolated mitochondria was measured using a Clark-type electrode (Yellow Springs Instruments) connected to a Gilson oxygraph using a standard reaction medium containing $0.25 \mathrm{M}$ sucrose, $10 \mathrm{mM}$ K-HEPES ( $\mathrm{pH} 7.2$ ), $2 \mathrm{mM} \mathrm{KCl}, 0.2 \mathrm{~g} \%$ essentially fat free bovine serum albumin (BSA), $2 \mathrm{mM} \mathrm{Pi}$ $\left(\mathrm{NaH}_{2} \mathrm{PO}_{4}\right), 10 \mu \mathrm{M}$ rotenone and $2 \mathrm{mM}$ succinate, in a final volume of $1.2 \mathrm{~mL}$ at $28^{\circ} \mathrm{C}$. No difference in oxygen uptake was found for mitochondria regardless of the presence or absence of ATP, showing that in our preparations the maximal rate of succinate oxidation was obtained. The respiratory rates are expressed in ng atom O. $\mathrm{min}^{-}$ ${ }^{1} . \mathrm{mg}^{-1}$, considering the oxygen solubility in water at $28^{\circ} \mathrm{C}$ and $1 \mathrm{~atm}$ as $233 \mu \mathrm{M}$ (Estabrook, 1967).

\section{NAD(P)H Oxidation Capacity}

The oxidation of $\mathrm{NAD}(\mathrm{P}) \mathrm{H}$ was measured indirectly by oxygen consumption in $1.2 \mathrm{~mL}$ of standard reaction medium at $28^{\circ} \mathrm{C}$ in the presence of $0.3 \mathrm{mg} \cdot \mathrm{mL}^{-1}$ of mitochondrial protein, disrupted by 3 cycles of freeze-thawing in liquid nitrogen in the presence or absence of $1 \mathrm{mM} \mathrm{Ca}{ }^{2+}$. The oxygen consumption was induced by the addition of $2 \mathrm{mM}$ NADH or NADPH. The rotenoneinsensitive $\mathrm{NAD}(\mathrm{P}) \mathrm{H}$ oxidation capacity was measured in the presence of $10 \mu \mathrm{M}$ rotenone. The rotenone-sensitive activity was determined as the difference between oxygen consumption in the presence and absence of rotenone. The NAD $(\mathrm{P}) \mathrm{H}$ oxidation capacity is expressed in ng atom O. $\mathrm{min}^{-}$ ${ }^{1} \cdot \mathrm{mg}^{-1}$.

\section{Protein Analysis}

Protein concentration were determined by the method of Lowry et al. (1951) using BSA as standard.

\section{Ultrastructural Analysis}

Samples (0.2 g) of A. angustifolia callus (20 days old), grown in the same culture medium, were fixed by immersion overnight in $4 \%$ paraformaldehyde, $2.5 \%$ glutaraldehyde in $0.1 \mathrm{M}$ cacodylate buffer, $\mathrm{pH} 7.2$, and submitted to low vacuum during the first $2 \mathrm{~h}$. Post-fixation was carried out in $1 \%$ osmium tetroxide in $0.1 \mathrm{M}$ cacodylate buffer, pH $7.2(1 \mathrm{~h})$, and dehydrated in an acetone series. Samples were embedded in Spurr resin. The samples were analyzed using a JEOL JEM-1200 EXII transmission electron microscope. Embedded tissue samples were sectioned and stained with $1 \%$ uranyl acetate in absolute ethanol for $20 \mathrm{~min}$ and then lead citrate for $5 \mathrm{~min}$.

\section{Chemicals}

NADH, NADPH, ADP, EGTA, BSA, rotenone, succinic acid, pyridoxine, nicotinic acid, thiamine, Hepes [N-(2-hydroxyethyl) piperazine-N'-(2ethanesulfonic acid)], glycine, casein hydrolyzate, myo-inositol, L-glutamine and FCCP (carbonyl cyanide 4-trifluoromethoxyphenyl-hydrazone), were purchased from Sigma Chemical Co. 
(St. Louis, USA). Phytagar was purchased from Gibco (Rockville, USA). All other reagents were commercial products of the highest purity available.

\section{RESULTS AND DISCUSSION}

We now present for the first time an effective procedure for the isolation of functionally intact mitochondria from the callus of $A$. angustifolia. Fig. 1 shows an electron micrograph of a thin $A$. angustifolia callus section in which the abundance of mitochondria can be seen.

\section{Isolation of Mitochondria from the Callus of} Araucaria angustifolia

In Fig. 2, a scheme showing the procedure used for the isolation of mitochondria from the callus of $A$. angustifolia, is presented. Mitochondria were isolated by conventional differential centrifugation, as previously described for the isolation of potato tuber mitochondria (Beavis and Vercesi, 1992 modified by Fortes et al., 2001) with modifications, as described below. The callus was first cut with scissors, then smoothly homogenized in a van Potter-Elvehjem homogenizer and after that disrupted in a Turratec homogenizer by $4 \mathrm{~s}$ bursts in the presence of a cold extraction medium containing $0.25 \mathrm{M}$ sucrose, $3 \mathrm{mM}$ cystein, $2 \mathrm{mM}$ EGTA, $0.2 \mathrm{~g} \%$ BSA, $10 \mathrm{mM}$ Na-Hepes, $\mathrm{pH}$ 7.6, (35 $\mathrm{g}$ of fresh callus $/ 200 \mathrm{~mL}$ medium). The homogenate was filtered through nylon cloth, and the $\mathrm{pH}$ was adjusted to 7.2. The filtrate was centrifuged for $10 \mathrm{~min}$ at $1000 \mathrm{Xg}$. The supernatant was centrifuged for $10 \mathrm{~min}$ at $15000 \mathrm{Xg}$ and each pellet was resuspended in wash medium $(0.25 \mathrm{M}$ sucrose, $0.25 \mathrm{mM}$ EGTA, $0.2 \mathrm{~g} \%$ BSA, $10 \mathrm{mM}$ Na-Hepes, $\mathrm{pH}$ 7.2) and transferred to a single tube and centrifuged for $10 \mathrm{~min}$ at $1000 \mathrm{Xg}$. The supernatant was centrifuged for $10 \mathrm{~min}$ at $15000 \mathrm{Xg}$. Mitochondria, found as a beige coloured pellet, were resuspended in one drop of wash medium and kept on ice until use.

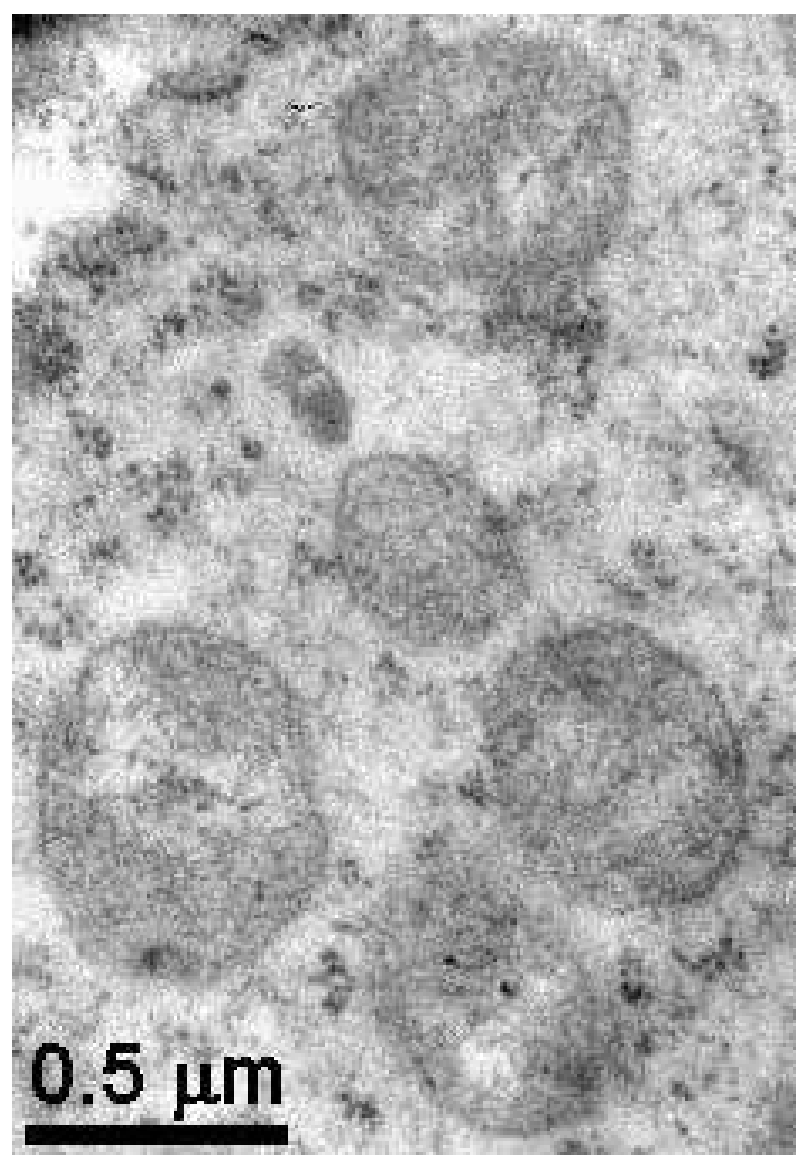

Figure 1 - Electron micrograph of a A. angustifolia callus cell (20 days old) showing the abundance of mitochondria. 




Figure 2 - Scheme demonstrating the procedure used for the isolation of mitochondria from callus of A. angustifolia.
Oxygen Uptake by $A$. angustifolia Mitochondria Fig. 3 shows the oxygen consumption in mitochondria of $A$. angustifolia respiring on succinate in the presence of $1 \mathrm{mM}$ phosphate. By addition of $150 \mathrm{nmol}$ ADP a respiration rate of 78 ng atom. $\mathrm{mg}^{-1} \cdot \mathrm{mL}^{-1}$ was attained (state 3 respiration) and recovery of the respiration to the resting state (state 4 respiration) of $36 \mathrm{ng}$ atom. $\mathrm{mg}^{-}$ ${ }^{1} . \mathrm{mL}^{-1}$ was obtained after exhaustion of the added adenine nucleotide.

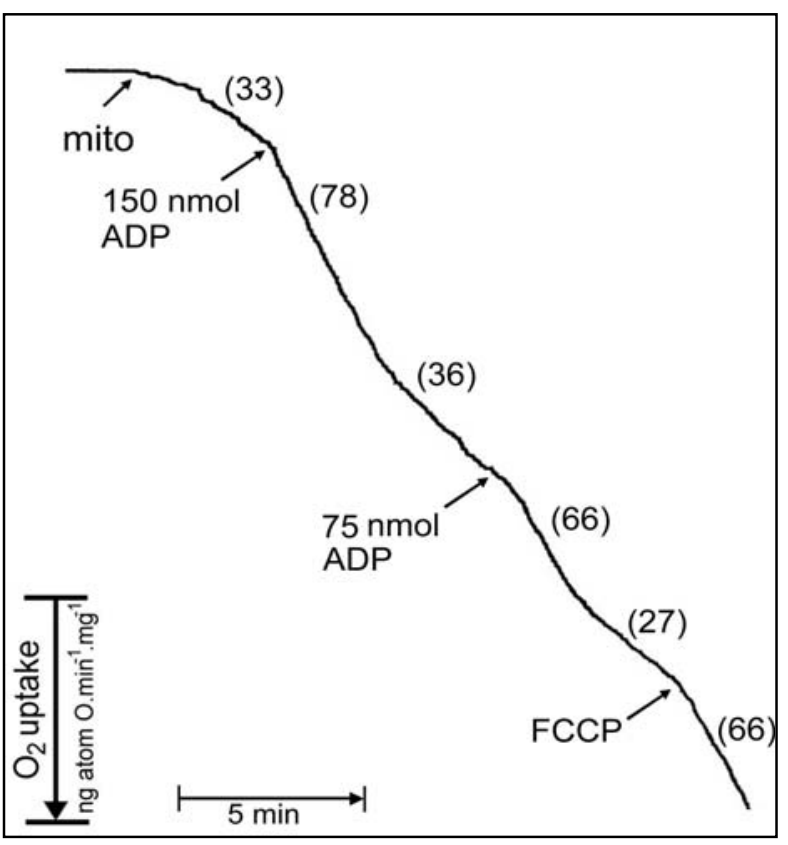

Figure 3 - Measurement of the respiration rate of isolated mitochondria from Araucaria angustifolia callus. The reaction medium contained $0.25 \mathrm{M}$ sucrose, $10 \mathrm{mM} \mathrm{K}$ HEPES (pH 7.2), $2 \mathrm{mM} \mathrm{KCl,} 0.2 \mathrm{~g} \%$ essentially fat-free BSA, $2 \mathrm{mM} \mathrm{Pi}, 10 \mu \mathrm{M}$ rotenone and $2 \mathrm{mM}$ succinate, in a final volume of $1.2 \mathrm{~mL}$, at $28^{\circ} \mathrm{C}$. The $\mathrm{O}_{2}$ uptake was induced by the addition of 0.3 $\mathrm{mg} \cdot \mathrm{mL}^{-1}$ mitochondrial protein. Other additions were: 150 and $75 \mathrm{nmol}$ ADP and $1 \mu \mathrm{M}$ FCCP as indicated. This figure is representative of 6 independent experiments.

There was state 3 and state 4 respiration again after further addition of $75 \mathrm{nmol}$ ADP to the incubation medium denoting the capability of the mitochondria to phosphorylation. The ratio between state 3 and state 4 , the respiratory control ratio, is a good index for the integrity of mitochondria. Thus 2.16 and 2.44 are good 
respiratory control indexes for plant mitochondria taking into consideration the possible presence of the ubiquitous alternative oxidase (AOX). AOX is an electron transferring oxidase, non-proton pumping, found in all plant mitochondria studied until now, which decreases considerably the respiratory control because of its uncontrolled respiration.

Fig. 3 also shows the increase in the oxygen consumption on addition of the protonophore FCCP, a well known uncoupler of mitochondria which acts causing the collapse of the mitochondrial internal membrane potential, through permeabilization of the membrane to protons.

\section{Alternative $\mathrm{NAD}(\mathrm{P}) \mathrm{H}$ Dehydrogenase and Complex I (EC 1.6.5.3) Activity}

Table 1 shows the oxygen consumption rate induced by the oxidation of NADH or NADPH in $A$. angustifolia mitochondria disrupted by freezethawing. Mitochondria show rotenone-insensitive $\mathrm{NADH}$ and NADPH oxidase activities that were increased by $\sim 18 \%$ and $40 \%$, respectively, by the addition of $1 \mathrm{mM} \mathrm{Ca}{ }^{2+}$. On the other hand, the rotenone-sensitive $\mathrm{NAD}(\mathrm{P}) \mathrm{H}$ oxidation was not affected by $\mathrm{Ca}^{2+}$ addition. This fact indicates the presence of the alternative $\mathrm{NAD}(\mathrm{P}) \mathrm{H}$ dehydrogenases in $A$. angustifolia mitochondria and also that their activities were modulated by the presence of $\mathrm{Ca}^{2+}$, like the external $\mathrm{NAD}(\mathrm{P}) \mathrm{H}$ and internal NADPH dehydrogenases that occur in potato tuber mitochondria (Melo et al, 1996). It could be concluded that complex I (EC 1.6.5.3) in these mitochondria was not affected by the addition of $\mathrm{Ca}^{2+}$ since this ion did not affect the rotenone-sensitive activity.

Table 1 - NAD(P)H oxidation capacity in freeze-thawed disrupted A. angustifolia mitochondria

\begin{tabular}{lrrr}
\hline & Total activity & Rotenone-insensitive activity & Rotenone-sensitive activity \\
\hline $\mathrm{NADH}$ & $54.6(4.9)$ & $38.5(1.6)$ & $16.1(4.3)$ \\
$+\mathrm{Ca}^{2+}$ & $62.2(10.2)$ & $45.6(2.1)$ & $16.6(8.1)$ \\
$\mathrm{NADPH}$ & $34.5(1.1)$ & $31.4(0.5)$ & $3.1(0.7)$ \\
$+\mathrm{Ca}^{2+}$ & $46.1(1.6)$ & $44.0(0.7)$ & $2.1(0.9)$ \\
\hline - Rates are in ng atom $\mathrm{O} . \mathrm{min}^{-1} . \mathrm{mg}^{-1}$ mitochondrial protein. Each value represents a mean \pm SD. Final concentrations were $2 \mathrm{mM}$ \\
$\mathrm{NADH}, 2 \mathrm{mM} \mathrm{NADPH}, 1 \mathrm{mM} \mathrm{Ca}^{2+}$ and $10 \mu \mathrm{M}$ rotenone. The plus sign indicates consecutive addition.
\end{tabular}

NADH, $2 \mathrm{mM}$ NADPH, $1 \mathrm{mM} \mathrm{Ca}^{2+}$ and $10 \mu \mathrm{M}$ rotenone. The plus sign indicates consecutive addition.

\section{CONCLUSIONS}

We now report an effective method for the isolation of mitochondria from the callus of Araucaria angustifolia. Using this protocol it was possible to measure the oxygen consumption by the mitochondria demonstrating that they were functionally intact and able to sustain oxidative phosphorylation, with a respiratory control of 2.4. The isolated mitochondria were sensitive to the protonophore FCCP, indicating that a transmembrane electrical potential was formed by energization and was sensitive to $\mathrm{H}^{+}$ permeabilization. A. angustifolia mitochondria possess alternative rotenone-insensitive $\mathrm{NAD}(\mathrm{P}) \mathrm{H}$ dehydrogenases, which were stimulated by $\mathrm{Ca}^{2+}$. However, the experiments on freeze-thawed mitochondria (Table 1) did not allow the identification of the alternative $\mathrm{NAD}(\mathrm{P}) \mathrm{H}$ dehydrogenases affected by $\mathrm{Ca}^{2+}$ and further studies with intact mitochondria are required.
The study of these alternative dehydrogenases and several other aspects of the respiratory chain of $A$. angustifolia mitochondria are of great importance, especially the study of AOX, as this is a conserved protein along evolution because of its occurrence in fungi, protozoa and plants (Siedow et al., 1995). The Araucariaceae family has an ancient origin in the Triassic Period and the araucarians appear to have maintained a preference for subtropical or mesothermal conditions, illustrated by the present distribution of A. angustifolia in southern Brazil (Kershaw and Wagstaff, 2001). A comparison between this ancient gymnosperm and the much more studied angiosperm mitochondria (Beavis and Vercesi, 1992; Fortes et al., 2001; Calegario et al., 2003; Ruy et al., 2004; Camacho et al., 2004) could be of great importance.

This isolation of A. angustifolia mitochondria could be an important new tool in studying plants, allowing several investigations on the metabolism 
and physiology of the plant and to understand the mechanisms for the maintenance of this species.

\section{ACKNOWLEDGEMENTS}

The authors thank Conselho Nacional de Desenvolvimento Científico e Tecnológico $(\mathrm{CNPq})$ and PRONEX for their financial support. The authors also thank Vera Regina Fontana Pionteke (Centro de Microscopia Eletrônica UFPR) for her technical assistance. A. B. M. is a graduate student supported by a CNPq scholarship. C. V. is an undergraduate student at Pontifícia Universidade Católica do Paraná and L. K. is a PIBIC/CNPq scholarship recipient.

\section{RESUMO}

Um procedimento de isolamento de mitocôndrias funcionalmente intactas de calos embriogênicos de Araucaria angustifolia foi desenvolvido pela primeira vez em nosso laboratório. Mitocôndrias isoladas por este método são metabolicamente ativas, capazes de sustentar fosforilação oxidativa como mostrado pelo controle respiratório de aproximadamente 2,4 , respirando na presença de succinato como substrato. Através de experimentos de consumo de oxigênio com mitocôndrias rompidas em nitrogênio líquido foi demonstrada a presença de NAD(P)H desidrogenases alternativas, insensíveis à rotenona e estimuladas por $\mathrm{Ca}^{2+}$. O isolamento de mitocôndrias de $A$. angustifolia é um novo e importante instrumento para estudar plantas, permitindo a execução de múltiplas investigações a respeito da bioenergética mitocondrial e fisiologia vegetal.

\section{REFERENCES}

Astarita, L. V. and Guerra, M. P. (2000), Conditioning of the culture medium by suspension cells and formation of somatic proembryo in Araucaria angustifolia (Coniferae). In Vitro Cell. Dev. Biol. Plant, 36, 194-200.

Beavis, A. D. and Vercesi, A. E. (1992), Anion uniport in plant-mitochondria is mediated by a $\mathrm{Mg}^{2+}$ insensitive inner membrane anion channel. J. Biol. Chem., 267, 3079-3087.
Calegario, F. F.; Cosso, R. G.; Fagian, M. M.; Almeida, F. V.; Jardim, W. F.; Jezek, P.; Arruda, P. and Vercesi, A. E. (2003), Stimulation of potato tuber respiration by cold stress is associated with an increased capacity of both plant uncoupling mitochondrial protein (PUMP) and alternative oxidase. J. Bioenerg. Biomembr., 35, 211-220.

Camacho, A.; Moreno-Sanchez, R. and Bernal-Lugo, I. (2004), Control of superoxide production in mitochondria from maize mesocotyls. FEBS Lett., 570, 52-56.

Chance, B. and Williams, G. R. (1955), The respiratory enzymes in oxidative phosphorylation: kinetics of oxygen utilization. J. Biol. Chem., 217, 383-393.

Estabrook, R. W. (1967), Mitochondrial respiratory control and the polarography measurement of ADP/O ratios. Methods Enzymology, 10, 41-47.

Fonseca, F. N.; Ferreira, A. J. S.; Sartorelli, P.; Lopes, N. P.; Floh, E. I. S.; Handro, W. and Kato, M. J. (2000), Phenylpropanoid derivatives and biflavones at different stages of differentiation and development of Araucaria angustifolia. Phytochemistry, 55, 575-580.

Fortes, F.; Castilho, R. F.; Catisti, R.; Carnieri, E. G. S. and Vercesi, A. E. (2001), $\mathrm{Ca}^{2+}$ induces a cyclosporin A-insensitive permeability transition pore in isolated potato tuber mitochondria mediated by reactive oxygen species. J. Bioenerg. Biomembr., 33, 43-51.

Guerra, M. P.; Silveira, V.; Santos, A. L. W.; Astarita, L. V. and Nodari, R. O. (2000), Somatic embryogenesis in Araucaria angustifolia (Bert.) $\mathrm{O}$. Ktze. In: Jain, S.; Gupta, P. and Newton, R. (Eds.). Somatic embryogenesis in woody plants. Dordrecht : Kluwer Academic Publishers. v. 6. pp. 457-478.

Kershaw, P and Wagstaff, B. (2001), The Southern conifer family Araucariaceae: history, status and value for paleoenvironmental reconstruction. Annu. Ver. Ecol. Syst., 32, 397-414.

Lowry, O. H.; Rosebrough, N. J.; Farr, A. L. and Randall, R. J. (1951), Protein measurements with the Folin phenol reagent. J. Biol. Chem., 193, 265-275.

Melo, A. M. P.; Roberts, T. H. and Møller, I. M. (1996), Evidence for the presence of two rotenone-insensitive $\mathrm{NAD}(\mathrm{P}) \mathrm{H}$ dehydrogenases on the inner surface of the inner membrane of potato tuber mitochondria. Biochim. Biophys. Acta (BBA), 1276, 133-139.

Melo, A. M. P.; Duarte, M.; Møller, I. M.; Prokisch, H.; Dolan, P. L.; Pinto, L.; Nelson, M. A. and Videira, A. (2001), The external calcium-dependent NADPH dehydrogenase from Neurospora crassa mitochondria. J. Biol. Chem., 276, 3947-3951.

Møller, I. M. and Palmer, J. M. (1982), Direct evidence for the presence of a rotenone-resistant NADH dehydrogenase on the inner surface of the inner membrane of plant mitochondria. Physiol. Plant., 54, 267-274. 
Møller, I. M. (2001), Plant mitochondria and oxidative stress. Electron transport, NADPH turnover and metabolism of reactive oxygen species. Annu. Rev. Plant Physiol. Plant Mol. Biol., 52, 561-591.

Ruy, F.; Vercesi, A. E.; Andrade, P. B. M.; Bianconi, M. L.; Chaimovich, H. and Kowaltowski, A. J. (2004), A highly active ATP-insensitive $\mathrm{K}^{+}$import pathway in plant mitochondria. J. Bioenerg. Biomembr., 36, 195-202.

Santos, A. L. W.; Silveira, V.; Steiner, N.; Vidor, M. and Guerra, M. P. (2002), Somatic embryogenesis in Parana pine (Araucaria angustifolia (Bert.) O. Kuntze). Braz. Arch. Biol. Tech., 45, 97-106.

Siedow, J. N.; Umbach, A. L. and Moore, A. L. (1995), The active site of the cyanide-resistant oxidase from plant mitochondria contains a binuclear iron center. FEBS Lett., 362, 10-14.

Zandavalli, R. B.; Dillenburg, L. R. and Souza, P. V. D. (2004), Growth responses of Araucaria angustifolia (Araucariaceae) to inoculation with the mycorrhizal fungus Glomus clarum. Applied Soil Ecology, 25, 245-255. 